\title{
Erratum on: Methamphetamine and the hypothalamic-pituitary-adrenal axis
}

\section{Frontiers Production Office*}

OPEN ACCESS

Approved by: Neuroscience Editorial Office,

Frontiers, Switzerland

*Correspondence: Frontiers Production Office, production.office@frontiersin.org

Specialty section:

This article was submitted to

Neuropharmacology,

a section of the journal

Frontiers in Neuroscience

Received: 18 June 2015

Accepted: 18 June 2015

Published: 26 June 2015

Citation:

Frontiers Production Office (2015)

Erratum on: Methamphetamine and the hypothalamic-pituitary-adrenal

axis. Front. Neurosci. 9:233.

doi: 10.3389/fnins.2015.00233

\section{An erratum on} 10.3389/fnins.2015.00178

Reason for Erratum:
Frontiers Production Office, Frontiers, Switzerland

Keywords: methamphetamine, stress, anxiety, substanceabuse, glucocorticoids, HPAaxis

Methamphetamine and the hypothalamic-pituitary-adrenal axis

by Zuloaga, D. G., Jacobskind, J. S., and Raber, J. (2015). Front. Neurosci. 9:178. doi:

Due to a misunderstanding, the last name of the author Jason S. Jacobskind was published as Jacosbskind. This error does not change the scientific conclusions of the article in any way.

The original article has been updated.

Copyright $\odot 2015$ Frontiers Production Office. This is an open-access article distributed under the terms of the Creative Commons Attribution License (CС BY). The use, distribution or reproduction in other forums is permitted, provided the original author(s) or licensor are credited and that the original publication in this journal is cited, in accordance with accepted academic practice. No use, distribution or reproduction is permitted which does not comply with these terms. 